\title{
Characterization of children and teenagers with ostomies in a health service
}

\section{Caracterização de crianças e adolescentes com estomas em um serviço de saúde}

\section{Caracterización de niños y adolescentes con ostomies in a health service}

Elaine Carininy Lopes da Costa 1*, Maria Helena Barros de Araújo Luz², Marcia Teles de Oliveira Gouveia², Elaine Maria Leite Rangel Andrade ${ }^{2}$, Paula Cristina Nogueira ${ }^{3}$

ORCID IDS

Costa ECL (D) https://orcid.org/0000-0002-5387-978X

Luz MHBA (iD https://orcid.org/0000-0003-1176-069x

Gouveia MTO (iD https://orcid.org/0000-0002-2401-4947

Andrade EMLR (iD https://orcid.org/0000-0002-1772-7439

Nogueira PC (iD https://orcid.org/0000-0003-4337-2675
HOW TO CITE

Costa ECL, Luz MHBA, Gouveia MTO, Andrade EMLR, Nogueira PC. Characterization of children and teenagers with ostomies in a health service. ESTIMA, Braz. J. Enterostomal Ther., 17: e0119. https://doi. org/10.30886/estima.v17.666 IN

*Extracted from: Costa ECL. Sociodemographic and clinical profile of children and adolescents with ostomies [dissertation]. Teresina (PI): Universidade Federal do Piauí, Departmento de Enfermagem; 2016.

\begin{abstract}
Objective: To characterize the socioeconomic and clinical profile of children and adolescents with ostomies attended at a public reference hospital in children's health in the state of Piauí, Brazil. Methods: Descriptive cross-sectional study of 55 children/adolescents with at least one ostomy. Results: There was a predominance of males, brown, mean age of 4.1 years. The main causes for the confection of the stoma were congenital malformations, especially the anomaly. Regarding the organic system, the gastrointestinal was the most affected and the colostomy was the most frequent. The majority of participants with elimination ostomies did not use collecting equipment. With regard to the complications of the stoma, the accidental release of the gastrostomy tube was the most common, followed by stomatal bleeding. Dermatitis was the most common skin complication. Conclusion: The realization of this study made it possible to know the socio-demographic profile of children and teenagers with ostomies and to promote reflections about nursing care to improve the assistance provided to these clients.
\end{abstract}

DESCRIPTORS: Surgical ostomies; Hospitalized children; Nursing; Stomatherapy; Kid; Health profile.

1.Instituto Federal do Piauí - Departamento de Enfermagem - Oeiras/PI - Brazil.

2.Universidade Federal do Piauí - Departamento de Enfermagem - Teresina/PI - Brazil.

3.Universidade de São Paulo - Escola de Enfermagem de Ribeirão Preto - Ribeirão Preto/SP - Brazil.

Corresponding author: ninyenfbio@ifpi.edu.br

Received: Nov. 21, 2018 | Accepted: Jan. 24, 2019 


\section{RESUMO}

Objetivo: Caracterizar o perfil socioeconômico e clínico de crianças e adolescentes com estomias atendidos em um hospital público de referência em saúde infantil do estado do Piauí, Brasil. Métodos: Estudo descritivo, transversal, realizado com 55 crianças/adolescentes, com pelo menos uma estomia. Resultados: Houve predomínio do sexo masculino, cor parda, média de idade de 4,1anos. As principais causas para confecção da estomia foram malformações congênitas, destacando-se a anomalia. Com relação ao sistema orgânico, o gastrintestinal foi o mais acometido e a colostomia foi a mais frequente. A maioria dos participantes com estomias de eliminação não utilizava equipamento coletor. Com relação às complicações da estomia, a saída acidental da sonda de gastrostomia foi a mais comum, seguida de sangramento da estomia. A dermatite foi a complicação da pele mais comum. Conclusão: A realização deste estudo possibilitou conhecer o perfil sociodemográfico de crianças e adolescentes com estomia e promover reflexões acerca do cuidado de enfermagem para a melhoria da assistência prestada a essa clientela.

DESCRITORES:Estomias cirúrgicas; Criança hospitalizada; Enfermagem; Estomaterapia; Criança; Perfil de saúde.

\section{RESUMEN}

Objetivo: Caracterizar el perfil socioeconómico y clínico de niños y adolescentes con estomias atendidos en un hospital público de referencia en salud infantil del estado de Piauí, Brasil. Métodos: Estudio descriptivo, transversal, realizado con 55 niños/adolescentes, con al menos una estomia. Resultados: Hubo predominio del sexo masculino, color pardo, promedio de edad de 4,1 años. Las principales causas para la confección de la estomia fueron malformaciones congénitas, destacándose la anomalía. Con respecto al sistema orgánico, el gastrointestinal fue el más acometido y la colostomía fue la más frecuente. La mayoría de los participantes con estomias de eliminación no utilizaba equipo colector. Con respecto a las complicaciones de la estomia, la salida accidental de la sonda de gastrostomía fue la más común, seguida de sangrado de la estomia. La dermatitis fue la complicación de la piel más común. Conclusión: La realización de este estudio posibilitó conocer el perfil sociodemográfico de niños y adolescentes con estomia y promover reflexiones acerca del cuidado de enfermería para la mejora de la asistencia prestada a esa clientela.

DESCRIPTORES: Estomias quirúrgicos; Niño hospitalizado; Enfermería; Niño;Estomaterapia; Perfil de salud.

\section{INTRODUCTION}

The word ostomy is of Greek origin and means “mouth". Its manufacture is done by surgery, in which an internal organ is externalized. In children and adolescents, the most common causes of ostomy confection are related to congenital malformation (anorectal anomaly and congenital mega colong anglionarum), necrotizing enterocolitis and traumas, and can be classified as temporary (there is a possibility of reconstruction of the organ) or definitive (when reconstruction of the organ is not possible); which will determine the possibility of reconstruction of the organ is the underlying disease and the necessary surgical interventions ${ }^{1,2}$.

In Brazil, there is no definitive data on the number of people with ostomies. According to the Ministry of Health, approximately one million and 400,000 surgical procedures are performed every year for the manufacture of ostomies ${ }^{3}$. Epidemiological data on the profile of people with ostomies in the country, especially the child and teenagers, are few. What is, in fact, are isolated local or regional studies characterizing sociodemographic and clinical profile that deal, for the most part, with adults or the elderly $y^{4,5}$.

The shortage of official information at the national and state levels, considering the profile of the child and teenagers with stoma, can hamper the planning and implementation of a policy of attention to this clientele, as well as hamper the execution of planning actions in the hospital and to allocate resources for the improvement of assistance to this specific group.

Therefore, the study of the profile of children and adolescents with stomies may contribute to the collection of relevant data on the topic, since it will allow the sizing of the characteristics and needs of these clients, serving as a subsidy for the health and social services, as well as for the planning of actions for integral assistance to children and adolescents with stomies, thus improving the quality of life of these people. Considering these points, the following objective was elaborated: to characterize the socioeconomic and clinical profile of children and adolescents with stomies attended at a public hospital 
of reference in children's health in Teresina, state of Piauí, Brazil.

\section{METHODS}

This is a cross-sectional descriptive study carried out in a public hospital in Teresina, a reference in the health care of children and adolescents, from July to October 2015. The population was composed of children and adolescents attended at this care center. Participants were chosen by convenience sampling. Thus, the total sample consisted of 55 participants, of which 46 children and nine adolescents met the following inclusion criteria: being a child or adolescent in an outpatient or inpatient treatment at that hospital and presenting, at the time of data collection, some type of ostomy. Children and adolescents whose records at the time of data collection were not available by the health team were excluded from the sample.

The identification of children or adolescents with ostomies was carried out through conversation with the surgeon's clerk or the inpatient nurse who, in possession of the medical records, indicated the children and adolescents with ostomies. After the identification of the children and adolescents, the parents or guardians were invited to participate in the research while in the waiting room, waiting for consultations with the health professionals, or during the period of hospitalization of the child or adolescent. The data collection was performed through a semi-structured questionnaire that investigated the following variables:

- Sociodemographic - Sex, age, level of schooling and family income;

- Clinics - System affected by the ostomies, type, format, coloration, anatomical location, implantation, medical diagnosis and cause for confection, length of permanence, existence, and type of complication and type of collection equipment;

- Surgical-Surgical technique and moment of surgery.

After the parents or guardians were informed about the accomplishment and the objectives of the research and had agreed to participate in the study, the Free and Informed Consent Form was signed, they answered the questionnaire. The questionnaire was completed by the researcher based on the answers of the parents or guardians of the children or adolescents with an ostomy, in the consulting of the study participants, as well as the physical examination of the child and/or adolescent, to evaluate the characteristics of the stoma.

Data were refined, tabulated, analyzed and presented in tables. All data from the observations and interviews were transposed to spreadsheets of the Microsoft Office Excel ${ }^{\circledast}$ 2010 software and later transported to the statistical package for Social Science (SPSS), version 20.0, for descriptive statistical analysis of the sociodemographic and clinical characteristics of children and adolescents through tables of distribution of absolute and relative frequency (percentage).

The research project was approved by the Ethics and Research Committee of the Universidade Federal do Piauí through n. 1.115.941 and is in accordance with Resolution 466/2012 of the National Health Council regarding the ethical aspects of research involving human beings. All participants were coded by interview number, and their true identities were not identified at any time, and anonymity was preserved.

\section{RESULTS}

Of the 55 study participants, 46 (83.6\%) were children and nine (16.4\%) were adolescents. Thirtythree (60\%) were males and 32 (58.2\%) were brown. As to age, there was variation between the minimum of 10 days and a maximum of 15 years and three months. The most frequent age group was one to four years, with 20 (36.4\%) children; Regarding the educational level, 45 (81.8\%) did not attend kindergarten or school. According to family income, those who had between one and two minimum wages predominated [26 (47.3\%)]. With regard to the benefit granted by the National Institute of Social Security (INSS) to the patients with stomies, the majority (36.5\%) of the children and adolescents did not receive the benefit.

In relation to the children, there was a predominance of gastrointestinal stomies [37 (74\%)]; colostomy was the most frequent [21 (42\%)], followed by gastrostomy [13 (26\%)] and, less frequently, ileostomy [3 (6\%)] and skin ostomy [1 (2\%)]. As for adolescents, gastrointestinal [6 (54.7\%)] stomies predominated, with gastrostomy 
being the most frequent $[4(36.6 \%)]$ and, less frequently, vesicostomy and cystostomy [1 (9.1\%) each] (Table 1).

When considering the basic causes for the manufacture of the ostomies in the children, the main one was the congenital malformation [34 (74\%)] and, in the adolescents, the congenital malformation and the cerebral palsy stand out [4 (44.4\%) each an]. Regarding the medical diagnoses in the child, the anorectal anomaly was the most frequent [19 (34\%)] and the least common was the congenital megacolon [2 (3.5\%)] cases. In adolescents, there was a higher frequency of esophageal reflux [4 (44.3\%)]. Other medical diagnoses, such as respiratory insufficiency, esophageal stenosis, necrotizing enterocolitis, posterior urethral valve, and urethral stenosis, are noteworthy (Table 2).

Table 1. Distribution of the ostomies in children and adolescents according to the organic system and type of stoma. Teresina. Piauí. Brazil. 2015 ( $n=55)$.

\begin{tabular}{ccc}
$\begin{array}{c}\text { Gastrointestinal } \\
\text { system }\end{array}$ & $\begin{array}{c}\text { Children } \\
\mathrm{n}(\%)\end{array}$ & $\begin{array}{c}\text { Adolescent } \\
\mathrm{n}(\%)\end{array}$ \\
\hline Colostomy & $21(42.0)$ & $2(18.1)$ \\
\hline Gastrostomy & $13(26.0)$ & $4(36.6)$ \\
\hline Ileostomy & $3(6.0)$ & - \\
\hline Respiratory system & Children $\mathrm{n}(\%)$ & Adolescent $\mathrm{n}(\%)$ \\
\hline Tracheostomy & $6(12.0)$ & $3(27.1)$ \\
\hline Urinary system & Children $\mathrm{n}(\%)$ & Adolescent $\mathrm{n}(\%)$ \\
\hline Vesicostomy & $6(12.0)$ & $1(9.1)$ \\
\hline Cystostomy & $-(2.0)$ & $1(9.1)$ \\
\hline Pielostomy & $1(2.0)$ & - \\
\hline Total & $50 *(100.0)$ & $11 *(100.0)$ \\
\hline
\end{tabular}

Source: direct research. ${ }^{*}$ The number of ostomies exceeds the number of participants. as some children and adolescents had more than one stoma.

Table 2. Distribution of children and adolescents with ostomies according to the basic causes and diagnosis for the confection. Teresina, Piauí, Brazil, 2015 ( $\left.n=55^{\star}\right)$.

\begin{tabular}{|c|c|c|c|}
\hline \multicolumn{2}{|c|}{ Variable } & \multirow{2}{*}{$\begin{array}{c}\text { Children n (\%) } \\
34(74.0)\end{array}$} & \multirow{2}{*}{$\frac{\text { Adolescents n (\%) }}{4(44.4)}$} \\
\hline & Congenital malformation & & \\
\hline \multirow[t]{2}{*}{ Basic causes } & Cerebral palsy & $7(15.2)$ & $4(44.4)$ \\
\hline & Others $^{\dagger}$ & $5(10.8)$ & $1(11.2)$ \\
\hline \multirow[t]{4}{*}{ Total } & - & $46(100.0)$ & $9(100.0)$ \\
\hline & Anorectal anomaly & $19(34.0)$ & $2(22.3)$ \\
\hline & Other diagnostics & $15(26.8)$ & $2(22.3)$ \\
\hline & Esophageal reflux & $6(10.7)$ & $4(44.3)$ \\
\hline \multirow[t]{4}{*}{ Medical Diagnostics } & Esophageal atresia & $6(10.7)$ & - \\
\hline & Hydronephrosis & $5(9.0)$ & $1(11.1)$ \\
\hline & PruneBelly Syndrome & $3(5.3)$ & - \\
\hline & Congenital Megacolon & $2(3.5)$ & - \\
\hline Total & - & $56(100.0)$ & $9(100.0)$ \\
\hline
\end{tabular}

Source: direct research. *The number of ostomies exceeds the number of participants, as some children and adolescents had more than one stoma. tOther causes, such as domestic accidents, infections, and visceral leishmaniasis. ‡ Other diagnoses, such as respiratory failure, caustic stenosis of the esophagus, enterocolitisecrosantus, posterior urethral valve, and urethral stenosis
As for the format, the round ostomies predominated [45 (73.8\%)] and the less frequent was oval shape [4 $(6.6 \%)]$. As for color, most were very bright red [38 (62.3\%)]. Considering the stomatal implantation in the skin, the most frequent were the flat $[33(54.1 \%)]$ and the less frequent were the retracted ones $[2(3.3 \%)]$. As to the location of the stoma, the lower left quadrant predominated [23 (36.5\%)] followed by those of the epigastric region [17 (27\%)]. Regarding the surgical technique for the preparation of intestinal ostomies, there was a predominance of the technique in two mouths [33 (53.8\%)] followed by the technique in the loop [23 (38.5\%)]. Regarding the nature of the surgery, $33(60 \%)$ performed it as a matter of urgency and $22(40 \%)$ did it on a scheduled basis.

Regarding the use of effluent collection equipment by the 34 children and adolescents with elimination stomies, it was verified that only seven (20.6\%) used such equipment. As to the types of devices used to feed the participants who had gastrostomy, the majority [13\% (76.6\%)] used the Foley catheter and only four (23.5\%) the low-profile type device Mic-Key valve.

Concerning complications in the ostomy, only children [8 (17.4\%)] presented them, and in four (50\%) the accidental release of the Foley catheter from the gastrostomy occurred, which is a complication of the device, three $(37.5 \%)$ had bleeding and one $(12.5 \%)$ prolapse in the ileostomy. When considering the peristomal skin, 13 (23.6\%) presented complications, being 11 children and two adolescents, with a predominance of irritative dermatitis [12 (92.3\%)] (Table 3). 
Table 3. Distribution of children and adolescents with stomies who presented complications of the conditions and peristaltic skin. Teresina, Piauí, Brazil, 2015 ( $n=55)$.

\begin{tabular}{|c|c|c|}
\hline \multicolumn{2}{|c|}{ Variables } & n (\%) \\
\hline \multirow{3}{*}{$\begin{array}{l}\text { Complication } \\
\text { of ostomy } \\
(n=8)\end{array}$} & $\begin{array}{l}\text { Gastrostomy tube } \\
\text { release }\end{array}$ & $4(50.0)$ \\
\hline & Bleeding & $3(37.5)$ \\
\hline & Prolapse & $1(12.5)$ \\
\hline \multirow{2}{*}{$\begin{array}{l}\text { Peristaltic skin } \\
\text { complications }(n=13)\end{array}$} & Irritant dermatitis & $12(92.3)$ \\
\hline & Pustule & $1(7.7)$ \\
\hline
\end{tabular}

Source: direct research

\section{DISCUSSION}

This study showed that the majority of children and adolescents with ostomies were male, which coincides with the results found in publications from Colombia, Nigeria, South Africa, South Korea, and Brazi1 ${ }^{6-14}$. On the other hand, there is a Brazilian study with a predominance of female children and adolescents with ostomies $^{15}$. Regarding skin color, the majority of the participants reported the color brown, which reflects the characteristics of the Northeast region, differing from the results of a study carried out in São Paulo, where there was a predominance of white color ${ }^{15}$.

When considering the age of the participants, we observed diversity of children from the neonatal, school, pre-school and early adolescence periods, ranging from a minimum of 10 days to 15 years and 3 months. This result is close to a study with children with ostomies in which there was a predominance of children in the age group of one to four years ${ }^{6,13,14}$.

As for gastrointestinal tract diseases resulting in the manufacture of ostomies, the literature shows that there is variation in the age group between children and adolescents, being common the occurrence from the first days of life until adolescence, but it occurs with greater prevalence in the age group between zero and five years ${ }^{9,16,17}$.

With regard to family income, there was a predominance of people with a family income between one and two minimum wages $(47.3 \%)$. These results coincide with those of other surveys of the profile of people with ostomies in which the family income prevailed below three minimum wages ${ }^{2,5,12,14}$. Families of children and/or adolescents with income up to a minimum wage $(34.5 \%)$ were also identified. Corroborating this finding, research with children and adolescents with ostomies showed families with per capita income lower than a minimum wage ${ }^{12,17}$. The income information allows concluding that the population studied has low purchasing power, which makes it difficult to acquire adequate collecting devices for the type of stomies, as well as the adjuvant accessories.

Regarding the educational level, it was verified that the majority did not go to school (81.8\%). This result is related to the age of the participants since $27.2 \%$ were younger than one year, that is, they were not yet of school age, which coincides with a study carried out in Belém ${ }^{14}$. Another reason pointed out by the parents concerns the insecurity in putting the ostomized kid to the school is because, according to them, these did not have teachers prepared for such clientele. In addition, they were afraid of the reaction of their colleagues, which influenced the decision not to enroll their children.

These results are similar to those found in a study with children with ostomy conditions, in which $74.4 \%$ of the interviewees did not go to school, the reasons being the age of the child ( $60 \%$ of infants), the child's health situation that prevented attending (neurological problems), the distance between school and home, parents' fear of effluent leakage and, consequently, the need to empty or exchange the bag, thus exposing the child ${ }^{6}$.

When considering the systems affected by the ostomies in the participants of the research, there was a predominance of ostomies in the gastrointestinal system (68\%). This result is similar to other studies in which it was the most affected ${ }^{13,14,18-21}$. Although the literature evidences that the gastrointestinal system is the most affected by ostomies in children and adolescents, it was possible to find studies in which the most affected organ system was the urinary system ${ }^{15}$.

With regard to the type of stoma, a colostomy was the most frequent. These results are similar to other studies with children with ostomies in which colostomy occurred more frequently $y^{10,12-14,17-24}$. It is worth noting in the literature the existence of other studies in pediatrics that show the predominance of urostomy, gastrostomy, and even ileostomy ${ }^{10,14}$.

With respect to the basic causes for the confection of the stomies in children and adolescents, the congenital malformations predominated. Thus, the results found in this study resemble those of the predominance of 
congenital malformations $\mathrm{s}^{8,10,12,17,21}$. Considering the intestinal stomies, there was a greater frequency of anorectal anomaly. Some studies with children with stomies corroborate these results ${ }^{12,19}$.

In contrast, in spite of the small number of cases of congenital megacolon found in this study, it was noticed in the literature that the frequency of this medical diagnosis for the manufacture of stomies in children was equal to that of anorectal anomaly and, in some studies, megacolon congenital heart disease was the most frequent ${ }^{7,9,14,16,18}$. In addition to the aforementioned causes, it was possible to find studies in which the main cause for the manufacture of the stomy was the trauma with abdominal perforation by firearm ${ }^{22}$.

With respect to the shape of the stoma, the round shape (73.8\%) was predominant and about the color, bright red stomies predominated. It is important to note that the normal features of a stoma are: bright pink or very vivid red color, regular shape, in which the body of the stoma presents the same shape of its base in the abdominal wall, bright and usually with mucus, whole skin and without changes (edema, bleeding, ulceration or nodules in its mucosa) $)^{13,24}$. Considering the location of the intestinal stomies, those located in the lower left quadrant predominated. Corroborating these results, research indicates the predominance of intestinal stomies located in the lower left quadrant ${ }^{24}$.

As for the surgical technique for the preparation of intestinal stomies, the technique was predominant in two mouths. In agreement with these findings, it was possible to find researches with a higher frequency of intestinal stomies performed using two-mouth technique ${ }^{13,21}$.In the two-mouth technique, the intestinal segment opens where the two mouths are joined, one proximal mouth, where the effluent leaves, and the other distal, which does not function and communicates with the rectum and the anus.

Regarding the nature of the surgery, most of them performed as a matter of urgency. Surgery for the construction of stomies in newborns is done in an emergency, usually a few days after birth, and it is unusual to demarcate the stoma site. Often the family has no power of choice, since the delay in performing the surgery may lead to worsening of the child's state of health for irreversible situations and even death ${ }^{24}$.

It is important to highlight that, in elective surgeries, nursing care should be performed effectively, starting in the preoperative period through the nursing consultation and the demarcation of the stomatal site by the stomatherapist nurse or nurse with specialized training; In this way, most of the complications with the ostomy and the peristaltic skin could possibly be avoided $^{24}$.

In this study, 34 participants with elimination stomies were observed, in which the majority (79.4\%) did not use effluent collection equipment, which was replaced by cloth diapers, and seven used fecal collecting equipment or urine. This result was also found in other studies carried out with children with stomies, in which the parents or family caregivers did not use collecting equipment, but cloth or gauze fixed with a bandage to contain the effluent ${ }^{2,16,18,23}$. The use of collecting equipment in people with elimination stomies is a right guaranteed by legislation and that enables a better quality of life and reduction of dermatitis.

When investigating the reasons for not using the collector equipment, it is worth mentioning the parents' difficulty in acquiring the bags, mainly of an economic nature, since most of them have incomes of up to two minimum wages, which makes it difficult to purchase the equipment. In addition, this study revealed that some parents were unaware of the program of distribution of collecting bags carried out in Teresina, which can demonstrate the parents' incipient orientation about the program by professionals involved in the care.

In support of these findings, a survey on the difficulties reported by family caregivers of children with ostomies highlighted the presence of family members who did not receive any type of orientation on the distribution pole of the collecting equipment, in addition to cases in which the relative only knew about the existence of the pole after one year of the making of the ostomy and that throughout this period cloth diapers were used to contain the effluents ${ }^{23}$.

Another reason pointed out by the parents concerns the lack of knowledge about the exchange and the hygiene of the collecting bag. This information is relevant, since it shows the fragility of nursing care not only to the children but also to their relatives, since the care of the child with the ostomy requires, from the family, the acquisition of new skills and abilities that are not part of their daily lives. Thus, they need the support of the professionals involved in the care, especially nursing 
Regarding the devices used to feed participants with gastrostomy, it was observed that the majority [13 (76.6\%)] used the Folley catheter for feeding. It is important to emphasize, once again, that the population studied has low income, which justifies the difficulty in acquiring low profile devices, such as the Mic-Key® valve. Thus, participants rely almost exclusively on the devices offered at the gastrostomy hospital, which most often provides the Folley type catheter because it is more economical.

With respect to complications related to the ostomies, it was observed that, of the total, only eight children presented complications with the ostomy, being more frequent the accidental escape of the probe of the gastrostomy followed by the bleeding in the ostomy and, less frequent, the prolapse of the stoma. This result corroborates the results of a study that also found, as a more frequent complication, the accidental escape of the feeding catheter ${ }^{25}$. On the other hand, unlike what was found in this study, when searching the literature for the main complications of intestinal stomies in children and adolescents, it has been identified in international studies that the prolapse of the stomach was the main complication found ${ }^{11,21}$.

In a study carried out in Brazil, complications occurred in $80 \%$ of the studied children, being the most frequent the bleeding in the place of the ostomy and the peristomal hernia ${ }^{16}$. In this study, $24 \%$ of the participants presented complications, with irritative dermatitis being the most prevalent $(92.3 \%)$. This finding corroborates the results of studies that reported the high frequency of irritative dermatitis, usually associated with inadequate handling of collecting equipment, as well as the contact of effluent released by the stoma, with special attention to ileostomy, in which alkaline effluent increases the risks for development of such lesions ${ }^{4,5,11}$. On the other hand, it was also possible to find, in the literature, research indicating the lower frequency of peristomal dermatitis ${ }^{12}$.

It should be emphasized that the presence of the elimination stoma requires that all healthcare personnel, especially nurses, take effective care in promoting health and preventing injuries, such as complications in the ostomies and peristomal skin ${ }^{12}$. In this perspective, the nurse should advise the parents and/or family about the care of the child or adolescent as a whole, since the making of the ostomy can lead to disorders in the various dimensions of the life of the child and the family. In addition, it is important that, in order to enable the insertion and success of this child or adolescent in school, the teacher is also a partner and receives, as well as parents, guidelines on the cleaning of the stomies, correct placement and removal, identification of aspects related to normalities and early manifestations of changes, making them able to develop preventive and rehabilitation actions.

It is important to highlight that, in addition to the care of the elimination stomies, the nursing team should also advise the parents or caregivers on the care of the gastrostomy, among which: cleaning with a physiological solution $0.9 \%$, the maintenance of clean and dry peristomal skin, washing of feeding equipment, use of skin spray or hydrocolloid around the stoma, as well as information on signs of gastrostomy complication and infection. Another important recommendation concerns the accidental release of the catheter. In this situation, the patient and/or family member should provisionally position it in the gastrostomy and seek medical assistance as soon as possible for their replacement, due to the risk of closing the stoma if that period exceeds 24 hours $^{26}$.

It is emphasized that the procedural technician is not enough; reception, qualified listening, the humanization of care and the guidelines on the rights of the person with the stoma are fundamental, among them the free acquisition of collecting equipment. In addition, it should be noted that, whenever possible, the child and adolescent are heard and included in the planning of actions for care and self-care.

\section{CONCLUSION}

With the development of this study, it was possible to trace the socioeconomic and clinical profile of children and adolescents with stomies who were in outpatient treatment or in the hospitalization unit of a public reference hospital in children's health in the state of Piauí, evidencing the predominance of participants male, brown, in the age group of one to four years, who were not yet attending school, the family income being between one and two minimum wages. With regard to the type of ostomies, the colostomy was the most frequent and the congenital malformation was the main cause for its confection. 
The study also evidenced children with elimination stomies that did not use effluent collecting equipment but rather a cloth diaper, and the reasons pointed out for such as a lack of knowledge of the parents regarding the handling of the collecting equipment and the way of acquiring this equipment, which may be related to the incipient orientation offered by health professionals, especially nurses and their staff. It is important to emphasize that most of the ostomies confected were performed as a matter of urgency, which prevented their previous demarcation, which may favor the appearance of complications, such as peristomal dermatitis

The study may contribute to health professionals, especially nurses, to promote reflections about their care practice and the planning of their actions based on the legislation in force and the rights of the person with the ostomy, such as having a well-defined stoma, receive guidance on care and free acquisition of collecting equipment and adjuvants. From this perspective, this reflection will contribute to the better planning of assistance to this clientele and to their parents and/or family members, resulting in an improvement in the quality of care provided.

Although the majority of the participants in this study did not attend school (81.8\%) because they were not of school age, attention was drawn to the parents' insecurity in enrolling the child with an ostomy, as they feared that teachers were unprepared for child care and the reaction of colleagues. It is imperative that teachers be prepared to receive and include the child and the adolescent in school and for this, the nurses can and should prepare them offering support, clear information, folders, and training.

The main limitations of this research were: delineation of the study, accomplishment in a single institution and the scarcity of publications that contemplated the morphological aspects of the stomies in children and adolescents.

\section{CONTRIBUTION OF AUTHORS}

Conceptualization,Costa ECL;Luz MHBA;Gouveia MTO; Andrade EMLR e Nogueira PC; Methodology,Costa ECL; Investigation, Costa ECL; Writing - First version: Costa ECL;Luz MHBA;Gouveia MTO; Andrade EMLR e Nogueira PC; Writing Review \& Editing,Costa ECL;Luz MHBA;Gouveia MTO; Andrade EMLR e Nogueira PC;Acquisition of Financing, CostaECL; Resources, Costa ECL; Supervision, Costa ECL.

\section{REFERENCES}

1. Coldicutt $P$, Hill B. An overview of surgical stoma construction and its effects on the child and their family. Nurs Child Young People. 2013;25(4):26-34.

2. Poleto D, Gonçalves MI, Barros MTT, Anders JC, Martins ML. A criança com estoma intestinal e sua família: implicações para o cuidado de enfermagem. TextoContextoEnferm. 2011;20(2):319-27.

3. LenzaNFB, Sonobe HM, BuettoLS, Santos MG, Lima MS. The teaching of self-care to ostomy patients and their families: an integrative review. Rev Bras Promoç Saúde Fortaleza;26(1):139-45.https://doi.org/10.5020/2644

4. Luz ALA, Luz MHBA. Caracterização de pessoas com estomias intestinais de eliminação na saúde da família: contribuição para a enfermagem. ESTIMA, Braz J Enterostomal Ther. 2014;12(2):35-5.

5. Luz ALA, Luz MHBA, Antunes A, Oliveira GS, Andrade EMLR, Miranda SM. Perfil de pacientes estomizados: revisão integrativa da literatura. Cult Cuid. 2014;18(1): 115-23.

6. Dias SM, Gonçalves FG. Percepções de familiares com criança estomizada sobre o grupo de apoio. ESTIMA, Braz J Enterostomal Ther. 2015;13(2):70-5.
7. Almeida EJ, Silva AL. Caracterização do perfil epidemiológico dos estomizados em hospitais da Secretaria de Estado de Saúde do Distrito Federal. ESTIMA, Braz J Enterostomal Ther. 2015;13(1):1-16. https://doi.org/10.5327/Z18063144201500010004

8. Rodrigues LN, Silva AMO, Xavier MS, Chaves EMC. Complicações e cuidados relacionados ao uso da gastrostomia em pediatria. ESTIMA, Braz J Enterostomal Ther. 2018;16(e1018):1-6. https://doi.org/10.30886/estima. v16.464 PT

9. Gamboa NSG, Álvarez LST. Cuidado de un hijo ostomizado: cambios en la familia. Avenferm. 2013;31(1):59-71.

10. Monteiro SNC, Kamada I, Silva AL, Souza TC. Perfil de crianças e adolescentes estomizados atendidos de um hospital público do Distrito Federal. ESTIMA, Braz J Enterostomal Ther. 2014;12(3):23-32.

11. Nam SH, Kim DY, Kim SC. Can we expect a favorable outcome after surgical treatment for an anorectal malformation? J Pediatr Surg. 2016;51(1):421-4. https://doi. org/10.1016/j.jpedsurg.2015.08.048.

12. Monteiro SNC, Kamada I, Silva AL. Qualidade de vida: percepção de crianças e adolescentes estomizados e 
seus pais e/ou responsáveis. ESTIMA, Braz J Enterostomal Ther. 2016;14(1):50. https://doi.org/10.5327/Z1806-31442 $\underline{01600010008}$

13. Costa ECL, Vale DS, Luz MHBA. Perfil das crianças estomizadas em um hospital público de Teresina, Piauí. ESTIMA, Braz J Enterostomal Ther. 2016;14(4):169-74. https://doi.org/10.5327/Z1806-3144201600040003

14. Bezerra PD, Pinto ISM, Cunha RR, Ramos EMLS, Silva CO, Ferreira SRM. Perfil sociodemográfico e clínico de crianças com estomias em um centro de referência, Belém (PA). ESTIMA, Braz J Enterostomal Ther. 2017;15(4):214-21. https://doi.org/10.5327/Z1806-3144201700040005

15. Melo MC, Kamada I. O papel da família no cuidado à criança com estoma intestinal: uma revisão narrativa. ESTIMA, Braz J Enterostomal Ther. 2015;13(3):121-6.

16. Rosado SR, DázioEMR, Siepiersk CT, Filipini CB, Fava SMCL. O cuidado de enfermagem e as lacunas na assistência à criança com estomias: uma revisão integrativa. ESTIMA, Braz J Enterostomal Ther. 2015;13(2):83-7.

17. Egito ETBN, Medeiros AQ, Moraes MM, Barbosa JM. Estado nutricional de pacientes pediátricos ostomizados. Rev Pau Pediatr. 2013;31(1):58-64

18. Menezes HF, GoésFG, Maia SM, Souza AL. A subjetividade no cuidado familiar à criança ostomizada a partir da construção da sua autonomia. RevPesquiCuid Fundam. 2016;5(2):37319. https://doi.org/10.9789/2175-5361.2013v5n2p3731

19. Rosado SR, DázioEMR, Fava SMCL, Maia PH, Filipini CB, ReskZMR. Experiência de ser mãe de criança com estomia. ESTIMA, Braz J Enterostomal Ther. 2014;12(1):12-20.

20. Santos OJ, Filho ENS, Filho AKDB, Desterro VS, Silva MVT, Prado RPS, et al. Children and adolescents ostomized in a reference hospital. Epidemiological profile. J Coloproctol. 2016; 36(2):75-9. https://doi.org/10.1016/j. jcol.2016.03.005.

21. ZacarinCFL, Alvarenga WA, Souza ROD, Borges DCS, Dupas G. Vulnerabilidade da família de crianças com estomia intestinal. RevEletr Enf. 2014;16(2):426-33. https://doi. org/10.5216/ree.v16i2.26639

22. Oda O, Davies D, Colapinto K, Gerstle T. Loop versus divided colostomy for the management of anorectal malformations. J Pediatr Surg. 2014;49(1):87-90. https:// doi.org/10.1016/j.jpedsurg.2013.09.032

23. Liechty ST, Barnhart DC, Huber JT, Zobell S, Rollins MD. The morbidity of a divided stoma compared to a loop colostomy in patients with anorectal malformation. J PediatrSurg. 2016;51(1):107-10. https://doi.org/https://doi. org/10.1016/j.jpedsurg.2015.10.025

24. SpenazatoRVS, Santos CRS, MaritaABPS, Paula MAB. Satisfação de clientes com estomias intestinais quanto ao uso de equipamentos. ESTIMA, Braz J Enterostomal Ther. 2016;14(4):193-202. https://doi.org/10.5327/Z18063144201600040006

25. Rodrigues LN, Silva AMO, Xavier MS, Chaves EMC. Complicações e cuidados relacionados ao uso do tubo de gastrostomia em pediatria ESTIMA, Braz J Enterostomal Ther. 2018;16:e1018. https://doi.org/10.30886/estima. v16.464_PT.

26. Silva TP, Ribeiro CRG, ResckZMR, Fava SMCL, DázioEMR. Cuidado de enfermagem à pessoa com gastrostomia: revisão integrativa. ESTIMA, Braz J Enterostomal Ther. 2018;16: e0718. https://doi.org/10.30886/estima.v16.374_PT 